\title{
Deconcentration of Chromium Contained in Wastewater Using a Bacteria and Microalgae Consortia with a High Rate Algal Reactor System
}

\author{
Bieby Voijant Tangahu ${ }^{1 *}$, Malik Berliantoº, Anak Agung Gde Kartika ${ }^{3}$ \\ 1 Department of Environmental Engineering, Faculty of Civil, Panning, and Geo Engineering, Institut Teknologi \\ Sepuluh Nopember, Jalan Raya ITS, Keputih, Sukolilo, Surabaya 60111, Indonesia \\ 2 Directorate of Coastal and Marine Pollution and Degradation Control, Directorate General of Environmental \\ Pollution and Degradation Control, Ministry of Environment and Forestry Republic of Indonesia \\ ${ }^{3}$ Department of Civil Engineering, Faculty of Civil, Planning, and Geo Engineering, Institut Teknologi Sepuluh \\ Nopember, Jalan Raya ITS, Keputih, Sukolilo, Surabaya 60111, Indonesia \\ * Corresponding author's e-mail: voijant@its.ac.id
}

\begin{abstract}
Heavy metal pollution has recently gained serious attention as an environmental issue. One example of heavy metal pollution in the natural water environment is chromium metal, which is released by several industries. Polyvalent chromium 6 is one of the most difficult environmental pollutants to remove due to its dissolvable and unstable properties. Bioremediation using a consortium of bacteria and microalgae in a High Rate Algal Reactor (HRAR) system can be expected to decrease the chromium concentration. The aim of this study was to determine the percentage of chromium removal by a bacteria and microalgae consortium and to determine the best ratio between these two kinds of microorganism in the context of pollutant reduction. The wastewater containing chromium that was used in this study was artificial wastewater with a chromium concentration of $17 \mathrm{mg} / \mathrm{L}$. The species of microalgae and bacteria were Chlorella vulgaris and Azotobacter S8. The chromium concentration used in the main experiment was determined through a preliminary Range Finding Test (RFT) for the microalgae and Minimum Inhibitory Concentration (MIC) for the bacteria. The chromium concentrations in RFT and MIC were 0 , $17,42,85,169$ and $339 \mathrm{mg} / \mathrm{L}$ and the variables in the main study were the respective Azotobacter S8 and Chlorella vulgaris compositions $(50: 50,75: 25,25: 75 \% \mathrm{v} / \mathrm{v})$. This, in addition to the variation in the consortium composition, was compared to the polluted media in the reactor $(5: 95$ and 10:90 \%v/v). Such parameters as $\mathrm{pH}$, temperature, total chromium concentration, microalgae cell count, and bacterial colonies were monitored during the experiments. The chromium deconcentration study was conducted over 7 (seven) days in a High Rate Algal Reactor (HRAR) with the microorganism inoculation conducted in the determined composition of artificial wastewater. The reactor was stirred for 24 hours per day and illuminated using artificial light at an intensity of $6000-7000$ lux. The deconcentration of chromium was analyzed using an Atomic Adsrober Spectrophotometer (AAS). The results showed that the highest chromium removal was reached in the reactor where the ratio of microorganisms and bacteria was 50\%:50\%, the initial inoculum of polluted media was 5\%: $95 \%$ and there was a chromium removal rate of $18.68 \%$. The consortium of Azotobacter S8 bacteria and Chlorella vulgaris microalgae can thus reduce the chromium concentration through the mechanisms of biosorption, bioaugmentation, and bioaccumulation.
\end{abstract}

Keywords: Azotobacter $S 8$, Chlorella vulgaris, consortium, chromium metals, high rate algal reactor

\section{INTRODUCTION}

The heavy metal pollution caused by either natural processes or human activity has become a serious environmental problem. The main cause of heavy metal pollution through either domestic or industrial activities is the water system pollution (Farombi et al., 2007). Chromium is one of the most common heavy metals found in the effluent produced by such industries as the electroplating 
industry, the metal industry, the tanning industry, cooling water, pulp, metal recovery and petroleum industries (Suminten, et al., 2014; Oves, et al., 2013). The chromium toxicity level and mobility is determined by the oxidation number. Naturally, chromium has an oxidation number of -2 to +6 (Evelyne and Ravisankar, 2014). However, only chromium (VI) and chromium (III) have the potential for being pollutants in several environmental systems (Kamaludeen, et al., 2003).

Chromium (VI), also known as $\mathrm{Cr}^{+}+$, is an unstable form. It is often found as chromate $\left(\mathrm{CrO}_{4}\right)^{2-}$ and/or dichromat $\left(\mathrm{Cr}_{2} \mathrm{O}_{7}\right)^{2-}$ and it has a higher mobility and toxicity than $\mathrm{Cr}^{3+}$ (Kamaludeen, et al., 2003; Evelyne and Ravisankar, 2014). Higher mobility chromium is more difficult to remove from the water body because of its dissolvable characteristic. The United States Environmental Protection Agency (US EPA) identified chromium as one of 17 chemicals that pose a threat to humans. It is classified as carcinogenic to humans through inhalation (USEPA, 2010). The pollution by chromium is therefore a concern.

Bioremediation is a form of pledge technology and it is cost-effective. It has recently been used to remediate soil or water that contains organic or inorganic contaminants (Kamaludeen, et al., 2003). Bioremediation can be conducted using many different kinds of microorganisms such as bacteria, fungi and microalgae through their respective biological processes. The bioremediation process utilizes the microorganism's natural abilities for the purpose of protection against heavy metals (Kaur and Kumar, 2014). On the basis of a recent study, Azotobacter bacteria (Pavel, et al., 2012) and Chlorella vulgaris microalgae (Brady, et al., 1994) are known to have the ability to remove chromium. Unfortunately, the study of the heavy metal removal by a bacteria and microalgae consortium is still rare. This is despite bacteria (aerobic bacteria) and microalgae consortiums being possible to construct because of the mutual symbiosis of these two kinds of microorganism. The bacteria support $\mathrm{CO}_{2}$ through its metabolism production as the raw material of the photosynthesis process of the microalgae in pollutant removal. Vice versa, the microalgae will produce $\mathrm{O}_{2}$ in the photosynthesis process, as it metabolizes the material for the bacteria. Both can change the bioavailability of heavy metal through the biosorption and biotransformation processes detailed here (Mujtaba and Lee, 2016).
Chlorella sp. is a microalga that has a high tolerance when it comes to pollutants and it is commonly found in the environment. Chlorella is often used in the wastewater treatment process (Man, et al., 2016). A study conducted by Cervantes, et al. in 2001 found that Chlorella vulgaris can reduce the amount of chromium by up to $83-99 \%$. In 2011, Subashchandrabose, et al. reviewed the research conducted by Rose et al. (1998) on wastewater treatment using a consortium of several different kinds of Cyanobacteria (blue-green microalgae) and bacteria. The study found that the consortium can reduce the level of iron by up to $100 \%$, zinc by $88 \%$ and copper by $79.2 \%$ in the tanning industry using a High Rate Algal Pond (HRAP) system. In 2016, Imron and Purwanti experimented with chromium (III) reduction using Azotobacter S8 and Bacillus subtilis in either a single species or consortium species approach. The study found that the highest removal of $10.53 \%$ was by Azotobacter S8 over a 4 hour exposure period. In this study, a consortium of Azotobacter S8 bacteria and Chlorella vulgaris microalgae was tested for the removal of chromium in water.

In this study, the consortium will be conducted in a High Rate Algal Reactor (HRAR) that replicates a High Rate Algal Pond (HRAP) modified to obtain a sterile environment. Because of its associated advantages, HRAP is one of the treatments that can be applied in Indonesia to reduce the level of chromium in wastewater. The experiment will be conducted under lighting in the reactor over 12 hours (Liang, et al., 2013; Nacorda, et al., 2010) with a fluorescent lamp (Maligan, et al., 2015) where the light intensity is between $6000-7000$ lux (Triatmojo and Tangahu, 2017). This is in order to give sufficient enough light for Chlorella vulgaris to execute the photosynthesis process so then it can support the growth of Azotobacter S8 inside the reactor.

\section{MATERIALS AND METHODS}

\section{Inoculum preparation of the initial bacteria and microalgae}

Microalgae cultivation was used to propagate the parent culture so then the experiment had a sufficient stock (Anderson, 2005). Microalgae cultivation was conducted by mixing $20 \%$ microalgae culture with $80 \%$ growth medium 
(Isnanstyo and Kurniastuty, 1995; Kawaroe, et al., 2010). The capacity of the reactor was 3L. It was filled with sterile seawater totaling 2,100 mL. Afterwards, $900 \mathrm{~mL}$ of parent culture via a sterile measurement glass was introduced into the reactor. Walne's fertilizer and vitamins were added at a concentration of $1 \mathrm{~mL}$ using a $10 \mathrm{~mL}$ micropipette (Isnanstyo and Kurniastuti, 1995).

The mixing process is known as inoculation. It was conducted under aseptic conditions (Purnamawati, et al., 2015; Maligan, et al., 2015) in the Laminar Air Flow equipment $20 \mathrm{~cm}$ from a Bunsen fire. Afterwards, the aerator pipe was placed inside the reactor. The cultivation was conducted up to the end of the log phase/microalgae exponential which was checked according to the growth curve test. Aeration was applied over 24 hours. The emitting light was 6000-7000 lux using a fluorescent lamp (Maligan, et al., 2015). The emitting period was 12/12 (Liang, et al., 2013; Nacorda, et al., 2010) and the temperature was $25-27^{\circ} \mathrm{C}$ (Nacorda, et al., 2010). After the end of the $\log$ phase/exponential period, the microalgae were harvested, placed into a sterile bottle and covered to avoid contamination. The seed was kept in the refrigerator at a temperature of $4^{\circ} \mathrm{C}$ and the seed was ready to use in the next step of the experiment (APHA, 2012; Tam, et al., 1998).

The microorganism activity related to chromium metal can be determined using the Inhibitory Concentration (MIC) test. In this study, the screening method used nutrient agar media to add the chromium in a range of concentrations. The final salinity of the media was around $30-35$ ppt and the chromium concentrations compared to the MIC were 0, 10, 25, 50, 100 and $200 \mathrm{mg} / \mathrm{L}$.

Bacterial growth was observed $24-168$ hours (7 days) after inoculation. The bacteria growth in the chromium-containing media was compared to the bacteria growth in the control media $(0 \mathrm{mg} / \mathrm{L})$. The MIC value was determined visually by counting the colony number in the Petri dish. A lower colony number represents the effect of chromium on the bacteria growth and the minimum chromium concentration that affects the bacteria growth can thus be determined. The selected concentration is known as the maximum concentration that can be tolerated by both microorganisms.

The Range Finding Test was used to determine the concentration of pollutant that can be tolerated by the microorganism being tested (in this study is microalgae) so then the microorganism can be kept alive and the treatment done optimally. The Range Finding Test was conducted using 5 different concentrations of chromium in reactors in order to measure the toxicity of wastewater containing chromium in relation to the Chlorella vulgaris microalgae. On the basis of the USEPA Guidelines 850.5400, a variation in concentration should be 5 in a geometrical tier with a ratio of 1.5 to 2 fitting the concentration in the MIC test regarding the bacteria.

The concentration to be tested was the ratio between the chromium concentrations of 0,10 , 25, 50, 100 and $200 \mathrm{mg} / \mathrm{L}$ in $250 \mathrm{~mL}$ after 7 days of velocity agitation at $130 \mathrm{rpm}$. If there were no microalgae dead after 7 days of exposure then the RFT was continued for up to 14 days. The result, its correspondence to the MIC result for the bacteria and the optimum concentration that can be removed by the consortium of bacteria and microalgae can thus be determined.

\section{Instrument and material sterilization}

The sterilization of any glassware was performed using an autoclave (ASC, Jerman) at a temperature of $121^{\circ} \mathrm{C}$ for \pm 2 hours. The sterilization of non-glassware was done by soaking it in chlorine liquid at a certain concentration for 30 minutes before washing it with aquadest and letting it dry. The Nutrient Agar (NA), Nutrient Broth (NB), stock solution, physiological solution and other material was sterilized using an autoclave. The media and material were placed inside the autoclave at a temperature of $121^{\circ} \mathrm{C}$ for \pm 60 minutes (Hossain, et al., 2012)

\section{Biodegradation test}

The test for chromium removal was conducted in a High Rate Algal Reactor (HRAR) with a total media volume of 8 liters. The microalgae nutrients, Walne's fertilizer and vitamins were added to the reactor at a concentration of $1 \mathrm{~mL} / \mathrm{L}$ compared to the media volume total. In this study, there were no nutrients added for the bacteria, because the HRAR system is a reactor used to propagate algae. The main focus of this study is the chosen microalgae without ignoring the role of bacteria in the overall process. The growth media was seawater with an initial salinity of $35 \mathrm{ppt}$ that was exposed to chromium from a stock solution of $\mathrm{K}_{2} \mathrm{Cr}_{2} \mathrm{O}_{7}$ with a concentration that is appropriate for both the MIC test and RFT test. These tests were conducted over 7 days. 
In this step, the parameters analyzed were $\mathrm{pH}$, temperature, salinity, the total concentration of chromium, the microalgae cell number and the bacteria colony number. The parameters of the bacteria colony in terms of number were analyzed on day- 0 , hour-4 (half exponential phase), hour-6 (exponential phase), day-1, day-4, and day-7. The microalgae cell number, $\mathrm{pH}$, temperature, and salinity were analyzed every 24 hours over 7 days. The total chromium concentration was analyzed at the beginning and the end of the experiment.

The variables in this study were the composition variations of the bacteria and microalgae mixture and the variation of the consortium and polluted media mixture in the reactor, as shown in Table 1.

On the basis of Table 1, the number of reactors used was 7 with a volume of \pm 12 liters. The reactors were $20 \mathrm{~cm}$ in length, $20 \mathrm{~cm}$ in width and $30 \mathrm{~cm}$ in height. The reactor was modified to have a cover and it was sterilized in order to avoid contamination from other microorganisms besides Azotobacter S8 and Chlorella vulgaris. In the HRAR reactor, the light exposure was done for 12 hours. The light intensity was the optimum light intensity using a fluorescent lamp that can support the microalgae growth ranging between 6000-7000 lux, as found in the study conducted by Tangahu, et al. in 2016 . There was also a control reactor without a microorganism inoculation. Figure 1 shows the reactor scheme for this study.

\section{RESULTS AND DISCUSSION}

\section{Chromium concentration tolerated by the microorganisms}

The Minimum Inhibitory Concentration (MIC) test for the Azotobacter $S 8$ bacteria and the

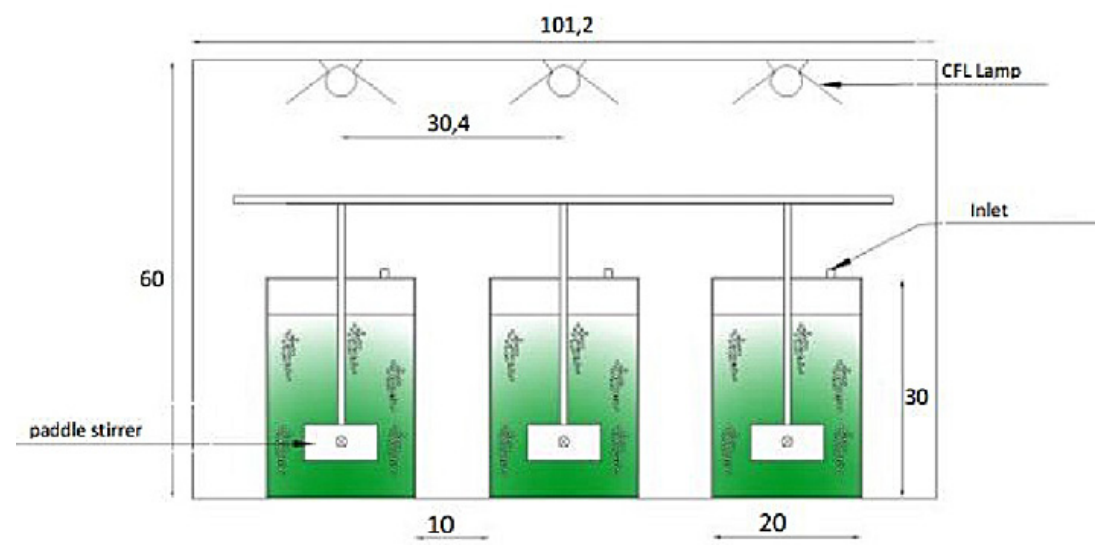

Figure 1. Reactor for chromium removal

Table 1. Variables of the consortium composition and the consortium composition and polluted media in the reactor

\begin{tabular}{|c|c|c|c|c|}
\hline \multicolumn{2}{|c|}{ Microorganisms composition (\%) } & \multicolumn{2}{c|}{ Consortium composition in the reactor (\%) } \\
\hline Azotobacter S8 & Chlorella vulgaris & Kode & $5 \%(\mathrm{~A})$ & \multicolumn{2}{c|}{ Control } \\
\hline 0 & 0 & $\mathrm{~K} 0$ & $\mathrm{~K} 1 \mathrm{~A}$ & $\left.\mathrm{~K}^{*} \mathrm{~B}^{*}\right)$ \\
\hline 25 & 75 & $\mathrm{~K} 1$ & $\mathrm{~K} 2 \mathrm{~A}$ & $\mathrm{~K} 2 \mathrm{~B}$ \\
\hline 50 & 50 & $\mathrm{~K} 2$ & $\mathrm{~K} 3 \mathrm{~A}$ & $\mathrm{~K} 3 \mathrm{~B}$ \\
\hline 75 & 25 & $\mathrm{~K} 3$ & \\
\hline
\end{tabular}

\section{Annotations:}

$\mathrm{K}=$ microorganism composition; $\mathrm{A}=$ consortium composition in reactor $5 \%$, pollutant $95 \%$; $\mathrm{B}=$ consortium composition in reactor $10 \%$, pollutant $90 \%$; K0 = without microorganisms (control); K1 = 25\% Azotobacter S8 and 75\% Chlorella vulgaris; K2 $=50 \%$ Azotobacter S8 and 50\% Chlorella vulgaris; K3 = 75\% Azotobacter S8 and $25 \%$ Chlorella vulgaris.

* In the composition of consortium and pollutant 10\%: 90\% (consortium volume $800 \mathrm{~mL}$ and pollutant $7.2 \mathrm{~L}$ ), there is $25 \%$ Azotobacter S8 with a cell density of 10.000 cell $/ \mathrm{mL}$ in absorbance 0,5 A dissolved in saline water at a $0.85 \%$ volume of $200 \mathrm{~mL}$. The $75 \%$ Chlorella vulgaris refers to the Chlorella vulgaris microalgae harvested in the mid-exponential phase of $600 \mathrm{mg} / \mathrm{L}$. This condition also applies to the other variation of 50\%:50\%. This means that the bacteria volume is the same as the microalgae volume which is $400 \mathrm{~mL}$ (10\% consortium) and/or $200 \mathrm{~mL}(5 \%$ consortium $)$. 
Range Finding Test (RFT) for the Chlorella vulgaris microalgae were conducted.

\section{Minimum Inhibitory Concentration (MIC) test of chromium - Azotobacter S8 bacteria}

The Minimum Inhibitory Concentration (MIC) test was conducted at 24 and 48 hours and continued up to 168 hours. The Azotobacter S8 bacteria were inoculated into the agar media that contained chromium in various concentrations that were determined in the preliminary test. The agar media was made with a mixture of $5 \mathrm{mLNA}, 5 \mathrm{~mL}$ pollutant and $70 \mathrm{ppt}$ salinity. The pollutant with an initial salinity of $70 \mathrm{ppt}$ was obtained from the dilution of a chromium stock solution with seawater before $\mathrm{NaCl}$ was added to reach the ideal salinity. This was to create a growth media with a salinity of 35 ppt apart from the other dilutions. This salinity of $35 \mathrm{ppt}$ supports the Chlorella vulgaris growth.

The next step was the screening method used to determine the concentration that was to be applied in the chromium removal test (Shrivastava, et al., 2013). The screening test results and incubation for $24-168$ hours were shown in Tables 2 and 3.

On the basis of Table 2, the higher chromium concentration exposed to the media shows lesser bacterial growth. In the media without chromium, the growth of Azotobacter S8 shows the best growth. The bacteria in a concentration of chromium at $17 \mathrm{mg} / \mathrm{L} \mathrm{K}_{2} \mathrm{Cr}_{2} \mathrm{O}_{7}$ also shows good growth. This condition shows that both concentrations can be tolerated by the bacteria.

In the $42 \mathrm{mg} / \mathrm{L}$ concentration, Azotobacter $S 8$ shows good growth after 72 hours incubation. This condition indicates that the Azotobacter S8 bacteria starts to have its growth inhibited by the increasing chromium concentration exposure. For the concentrations of $85 \mathrm{mg} / \mathrm{L}, 169 \mathrm{mg} /$ Land $339 \mathrm{mg} / \mathrm{L} \mathrm{K}_{2} \mathrm{Cr}_{2} \mathrm{O}_{7}$, there was no growth. Pavel et al. (2012) found that Azotobacter $S 8$ has a high tolerance for chromium concentrations of $0-50 \mathrm{mg} / \mathrm{L}$.

The MIC test was used to score the results. The MIC scoring was determined based on the area of bacterial growth on the surface media and the color change compared to the bacterial growth on the control media. The area of bacterial growth on the media surface was of the greatest concern. The spread of bacterial growth on the media shows that the bacteria can survive in the polluted media. The scoring criteria used for the MIC observation in this study were as follows:
+++++ Area of bacterial growth on the polluted media compared with the area of bacterial growth on the control media $81-100 \%$ and/or no color change;

++++ Area of bacterial growth on the polluted media compared with the area of bacterial growth on the control media $61-80 \%$ and/ or no color change;

++ Area of bacterial growth on the polluted media compared with the area of bacterial growth on the control media $41-60 \%$ and/ or no color change;

$+\quad$ Area of bacterial growth on the polluted media compared with the area of bacterial growth on the control media $21-40 \%$ and/ or color change;

$+\quad$ Area of bacterial growth on the polluted media compared with the area of bacterial growth on the control media $<20 \%$ and/or color change;

- $\quad$ No bacterial growth observed.

The scoring results for the bacterial growth in the MIC test are as shown in Table 4. It shows that the MIC value for the bacteria observed at the concentration of $42 \mathrm{mg} / \mathrm{L}$ is $\mathrm{K}_{2} \mathrm{Cr}_{2} \mathrm{O}_{7}$. At that concentration, the growth of Azotobacter S8 will be inhibited. The Maximum Tolerance Concentration (MTC) value of Azotobacter S8 is $17 \mathrm{mg} / \mathrm{L}$. The Minimum Bactericidal Concentration (MBC) value is the minimum concentration that can kill $99.9 \%$ of Azotobacter S8 in the media. The MBC value is $85 \mathrm{mg} / \mathrm{L}$.

\section{Range Finding Test (RFT) of the chromium for Chlorella vulgaris microalgae}

The Range Finding Test (RFT) was used to determine the concentration of pollutants that can be tolerated by the microorganism test (in this study, this was the microalgae). This means that the microorganism can remain alive and complete the treatment optimally. The Range Finding Test was conducted by assessing 5 different concentrations of chromium in the reactors in order to measure the toxicity of the wastewater containing chromium compared to the Chlorella vulgaris microalgae. On the basis of the USEPA Guidelines 850.5400 , the variation in concentration should be across 5 geometric tiers with a ratio from 1.5 to 2 that fits the concentration used in the MIC test for the bacteria; $0 \mathrm{mg} / \mathrm{L}$ was the control while $17 \mathrm{mg} / \mathrm{L}, 42 \mathrm{mg} / \mathrm{L}, 85 \mathrm{mg} / \mathrm{L}, 169 \mathrm{mg} / \mathrm{L}$ and $339 \mathrm{mg} / \mathrm{L}$ were tested otherwise. The test was 
Table 2. Minimum Inhibitory Concentration (MIC) test result to Azotobacter S8 in chromium concentration 0 , 17 , and $42 \mathrm{mg} / \mathrm{L}$

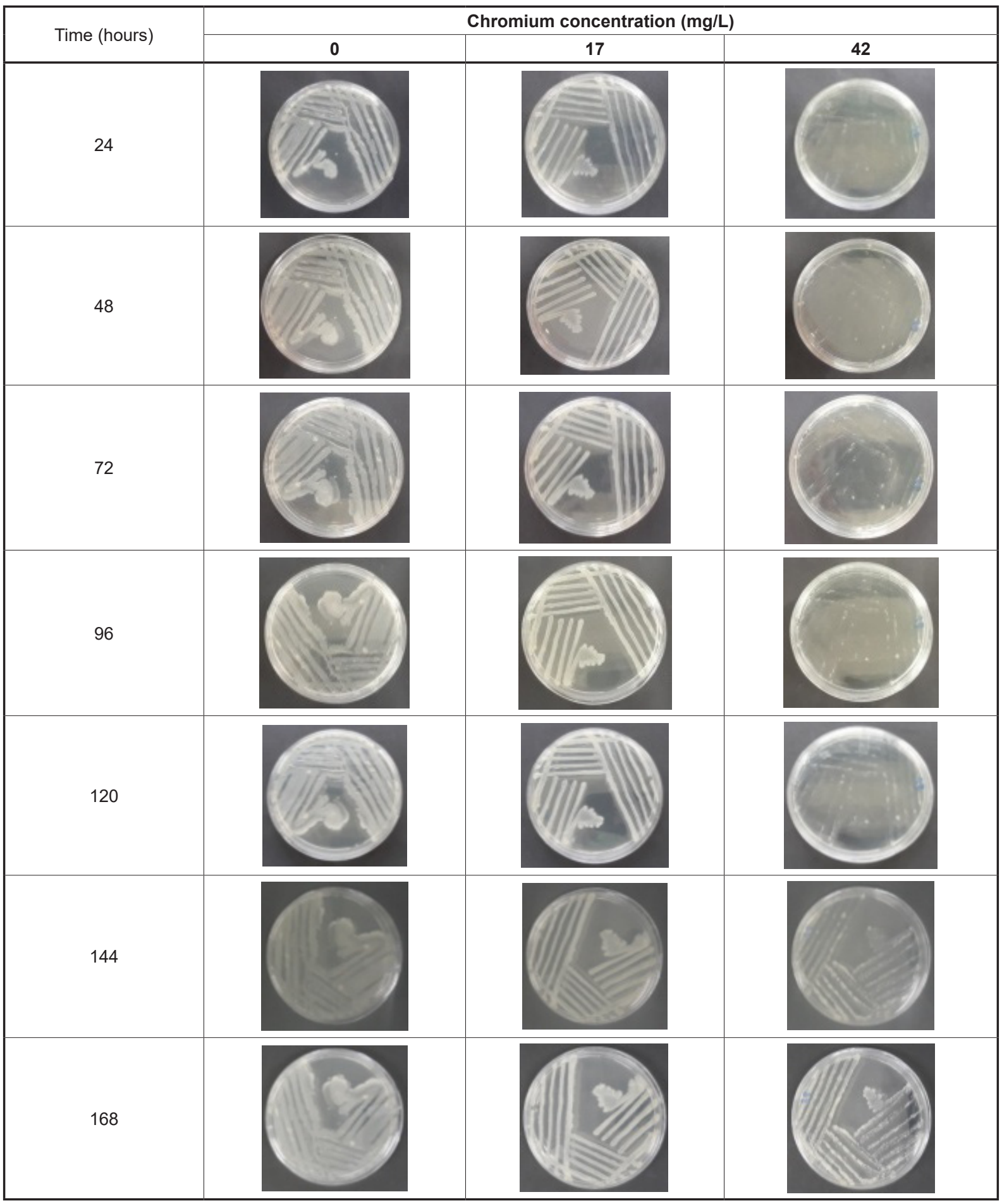

conducted in $250 \mathrm{~mL}$ Erlenmeyer for 7 days with light emitting at 6000-7000 lux, with a ratio of dark to light of $12 / 12$. The shake velocity was $130 \mathrm{rpm}$. The ratio of inoculum and media was 10\%: $90 \%$. The polluted media was made using dilute chromium stock solution with seawater. The media was sterilized using an autoclave at $121^{\circ} \mathrm{C}$ with $1.1 \mathrm{~atm}$ pressure. The nutrients came from Walne's fertilizer and vitamins were also added to the media at a concentration of $1 \mathrm{~mL} / \mathrm{L}$ media. The counting of the Chlorella vulgaris cells was done on day- 0 , day- 4 and day- 7 . The counting results for the Chlorella vulgaris cells are as shown in Table 5.

The Range Finding Test result showed that the best growth rate was at the pollutant 
Table 3. Minimum Inhibitory Concentration test result to Azotobacter S8 in chromium concentration of 85, 169, and $339 \mathrm{mg} / \mathrm{L}$

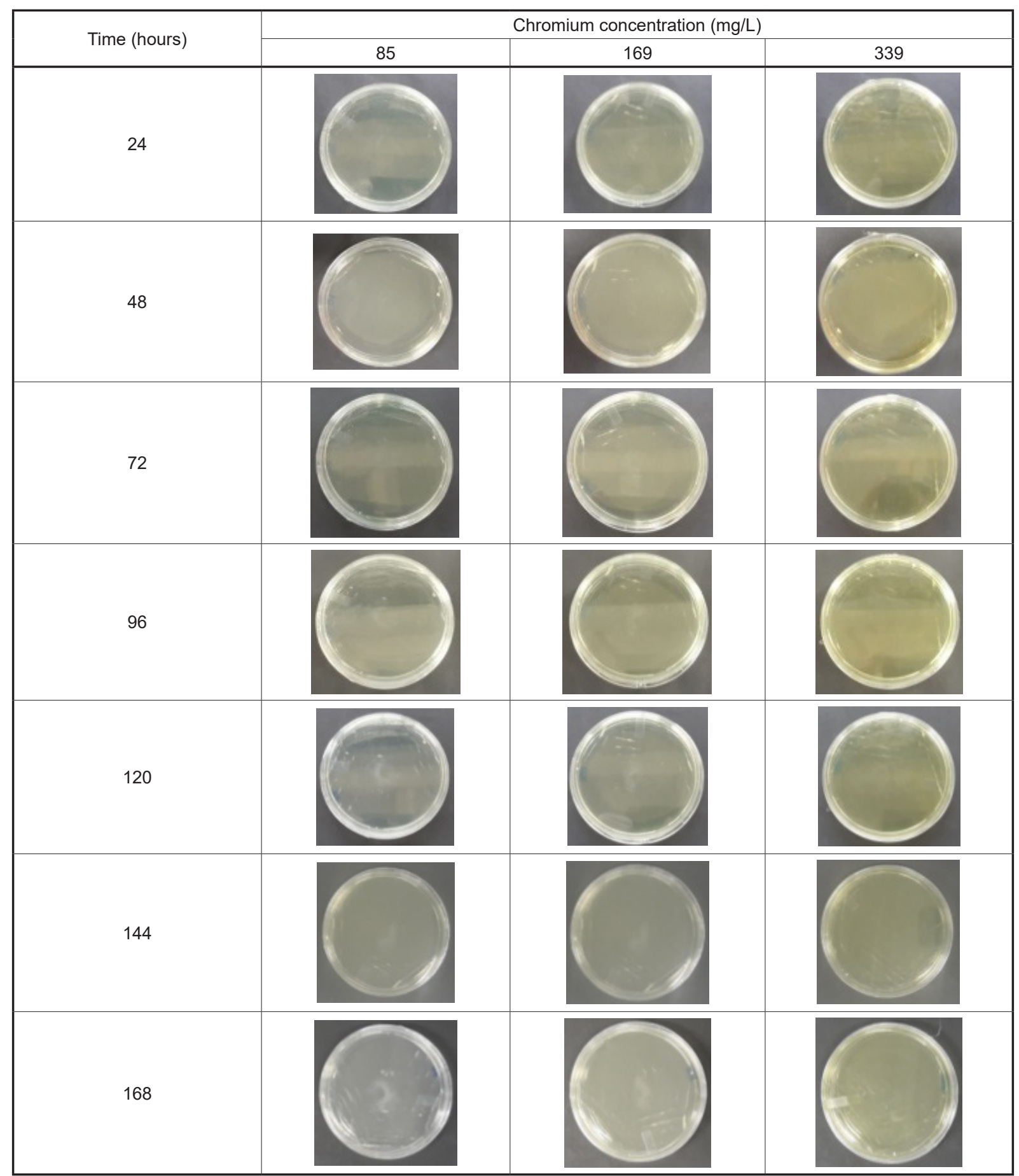

concentration of $17 \mathrm{mg} / \mathrm{L}$ with a growth effect of $122 \%$ compared with the 4 other concentrations. Only in concentration $17 \mathrm{mg} / \mathrm{L}$ was the number of cells increased by day-4. On the basis of the physical observation, color was found only for the concentration of $17 \mathrm{mg} / \mathrm{L}$. Table 2 shows the physical observation results for the RFT.

Table 4. Scoring of bacteria growth on MIC test

\begin{tabular}{|c|c|c|c|c|c|c|}
\hline \multirow{2}{*}{ Bacteria } & \multicolumn{6}{|c|}{ Concentration of $\mathrm{K}_{2} \mathrm{Cr}_{2} \mathrm{O}_{7}(\mathrm{mg} / \mathrm{L})$} \\
\cline { 2 - 7 } & 0 & 17 & 42 & 85 & 169 & 339 \\
\hline Azotobacter S8 & +++++ & ++++ & + & - & - & - \\
\hline
\end{tabular}


The MIC and RFT results showed that both microorganisms have the same tolerance value compared to the chromium in the $17 \mathrm{mg} / \mathrm{L}$ concentration. A toxicity test was conducted on the consortium microorganisms in order to determine the exact value of the maximum tolerance concentration of both microorganisms in the consortium. On the basis of this result, the main experiment was conducted in a chromium concentration of $17 \mathrm{mg} / \mathrm{L}$. Then, the removal of the chromium by the consortium of Azotobacter S8 bacteria and Chlorella vulgaris microalgae was tested. This result also proves that both microorganisms are aerobic. This is because $\mathrm{K}_{2} \mathrm{Cr}_{2} \mathrm{O}_{7}$ is known to be a strong oxidizer that can release oxygen into the media (Holleman, et al, 1985).

\section{Deconcentration of Chromium}

The chromium total parameter measurement was performed at the start and end of the experiment. This study aimed at determining the removal percentage of chromium by the bacteria and algae consortium. The experiment was conducted in duplicate and the chromium total was the average value across both experiments. The parameter analysis was conducted with Atomic Absorption Spectroscopy (AAS). The results of the total chromium analysis can be seen in Table 3 .

Table 3 shows that the chromium concentration decreased in the reactor with an inoculum of the consortium of Azotobacter S8 and Chlorella vulgaris. It has been proven that the consortium can remove the heavy metal chromium. Bacteria and microalgae need chromium as a nutrient at a lower concentration in order to stay alive (Benazier et al., 2010). It can be seen that in the control reactor with decreased chromium concentration, even if there is no inoculation of bacteria and algae. This is caused by the unstable chromium liquid and the uncontrolled $\mathrm{pH}$ of the chromium liquid itself. Abdulla, et al. (2010) stated that decreasing the level of chromium in the control reactor may cause a spontaneous reduction or adhesion in the surface reactor. This is because of the environmental influences such as temperature and agitation velocity. On the basis of the bacteria total colony test, in the control reactor, the contaminant bacteria were found on day- 0 . This was caused by several factors, one of which is improper reactor sterilization. The removal percentage is shown in Figure 3.

Figure 3 indicates that the highest removal is $18,68 \%$ by the consortium ratio of $50 \%$ Azotobacter S8 and 50\% Chlorella vulgaris with the initial inoculum in the reactor being 5\%. The lowest percentage was $8.14 \%$ for the consortium of $75 \%$ Azotobacter S8 with 25\% Chlorella vulgaris. The initial inoculum in the reactor was $5 \%$ during the 7 day exposure.

The next step was testing the dry biomass using the Scanning Electron Microscope-Energy Dispersive X-Ray Spectroscopy (SEM-EDX) method. This test makes sure that the removal of chromium is done by the consortium and that the chromium form that is removed is chromium (VI). The dry biomass can also be measured using the gravimetric method so it can be confirmed that a decreasing percentage of removed chromium is the result of the consortium originating from chromium (VI).

On the basis of the Pourbaix diagram, the $\mathrm{K}_{2} \mathrm{Cr}_{2} \mathrm{O}_{7}$ liquid (used in this study as artificial wastewater) in the pure water has a base $\mathrm{pH}$ (average $\mathrm{pH}$ in reactor 6.97-7.31) that will form $\mathrm{CrO}^{4-}$, which has a yellow color. This corresponds to the color change of the wastewater during the experiment. The chromium uptake is $\mathrm{Cr}^{6+}$, also known as hexavalent chromium.

According to Nithya et al. (2011), the bacterium that is available in the heavy metal-polluted environment will have a level of resistance through the processes of biosorption and bioaccumulation. Azotobacter S8 has eksopolisakarida (EPS) in its cell wall that has the function of chelating the heavy metal on its surface cell (Iyer, et al., 2005). This cell character can cause the heavy metal to be absorbed by the Azotobacter (Erni and Hindersah, 2011). The ability of Azotobacter S8 to engage in the extracellular

Table 5. Cell number of Chlorella vulgaris on RFT (in 105 cell $/ \mathrm{mL}$ )

\begin{tabular}{|c|c|c|c|c|c|c|}
\hline \multirow{2}{*}{ Day } & \multicolumn{5}{|c|}{ Chromium Consentration (mg/L) } \\
\cline { 2 - 7 } & 0 & 17 & 42 & 85 & 169 & 339 \\
\hline 0 & 7.1 & 6.08 & 6 & 6.18 & 5.34 & 7.02 \\
\hline 4 & 34.86 & 19.24 & 5.94 & 4.3 & 5.56 & 5.3 \\
\hline 7 & 1400 & 7.42 & 4.98 & 6.86 & 4.32 \\
\hline
\end{tabular}




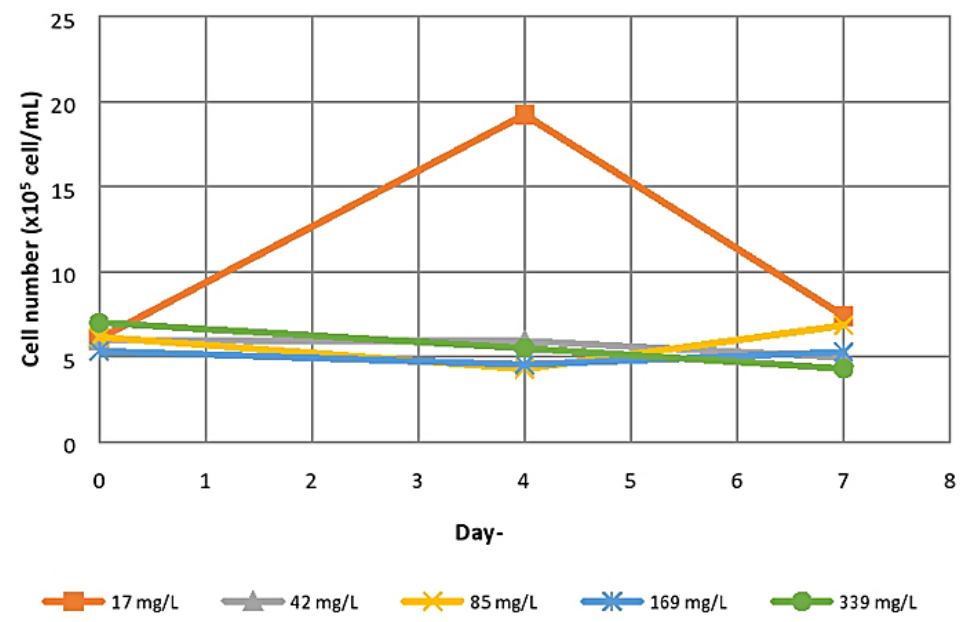

Figure 2. The growth of Chlorella vulgaris in the RFT

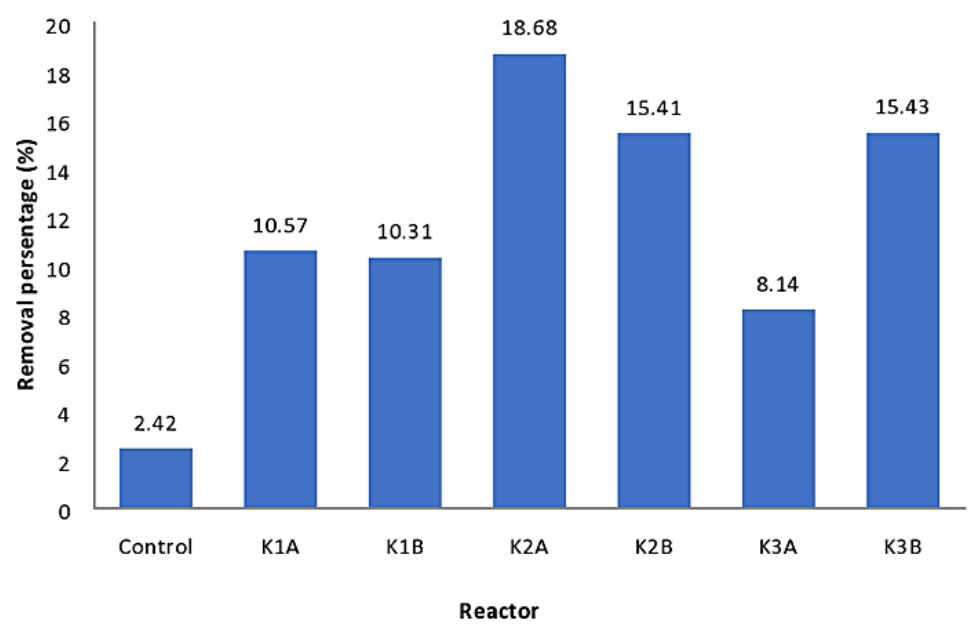

Figure 3. Removal of chromium by the bacteria and microalgae consortium

detoxified mechanisms is also influenced by the interaction of chromium with a hydroxyl group in the cellulose that coats the bacteria cell wall. Azotobacter also produces catalase and reductase enzymes (Nath and Ray, 2015). These enzymes function to break down the toxic material that enters the bacterial cells, reducing the toxicity concentration of the pollutants, especially heavy metal. The bioaccumulation mechanisms inside the bacteria cells are related to metal accumulation (Silver, 1996).

The metal removal process also involves the biosorption, biotransformation and bioaccumulation mechanisms. Imani et al. (2011) stated that the key factor in metal remediation is the non-biodegradable characteristic of the metal. It can transform through the processes of sorption, methylation, complexation and changes in valence. According to Droste (2007), when heavy metal ions are spread around the cell, the ions bond to the elements that are available in the cell wall based on the affinity power of the cell.

Purnamawati, et al. (2015) stated that before the metal ions reach the cell membrane and cell cytoplasm, they have to pass through the microalgae cell wall that contains various polysaccharides and proteins. There are several active sites that can bind to the metal ions. In the cell wall, monovalent and divalent ions (such as $\mathrm{Na}, \mathrm{Mg}$, and $\mathrm{Ca}$ ) exchange heavy metal ions and then form complex formations consisting of heavy metal ions paired with functional groups such as carbonyls, aminos, thiols, hydroxyls, phosphates and hydroxy-carboxyls. This process is known as biosorption.

The biosorption process takes place fast and it is reversible in either dead or living cells. This process is most effective at a certain $\mathrm{pH}$ and in the presence of other ions (Tortora, 2001; Glick and Pasternak, 2001). This is why the cell walls 
are often stated as being the most important part of the cell defense mechanism. This is caused by the cell walls being the first barrier to toxic heavy metal accumulation.

According to Esmaeili (2015), Chlorella vulgaris can synthesize the protein chelation of metal through active processes using the glutathione that is available in all cells. If metal pollution occurs, glutathione will form a phytochelatinmetal that is forwarded to the vacuole (Haryoto and Agustono, 2004). For example, if there is $\mathrm{Cr}$ pollution, it will form phytochelatin $-\mathrm{Cr}$. The $\mathrm{Cr}$ absorption influences the $\mathrm{pH}$ medium:

$$
2 \mathrm{~S}-\mathrm{H}+\mathrm{Cr}^{6+} \rightarrow \mathrm{S}-\mathrm{Cr}^{3+}-\mathrm{S}+2 \mathrm{H}^{+}
$$

where: $S-H$ - absorbant/thiol group on phyitochelatin (Dasta and Tabati, 1992 in Haryoto and Agustono, 2004).

According to Purnamawati, et al. (2015), Cr accumulation will increase the $\mathrm{H}^{+}$ion concentration. Because of the equilibrium reaction, the increase of the $\mathrm{pH}$ medium will cause a reaction shift in the $\mathrm{H}^{+}$ion production. This means that there will be an increased number of complex $\mathrm{Cr}$ because of the metal release. The constant rate is lower than its absorption rate and the metal ions will tend to stay inside the cell. The absorption process and toxic material accumulation inside the cell will be broken down and excreted, saved and metabolized by the organism depending on the concentration and chemistry potential of the material.

Both microorganisms, Azotobacter S8 and Chlorella vulgaris, remove chromium through the same processes of biosorption, biotransformation, biomineralization and bioaccumulation. The locations of the interactions come from the availability of oxygen which is an energy source for the bacteria. Mujtaba and Lee (2016) stated that the consortium interaction process between bacteria and microalgae happens through the $\mathrm{O}_{2}-\mathrm{CO}_{2}$ exchange. Carbon dioxide from the Azotobacter S8 respiration is needed for the photosynthesis process of Chlorella vulgaris. Vice versa, the oxygen from the photosynthesis process will be used in the metabolism of Azotobacter S8. This is evidenced by a mixture of $50 \%$ Chlorella vulgaris and 50\% Azotobacter S8 which results in the highest chromium deconcentration. According to the experiment results, the main actor or removal determinant is the Azotobacter

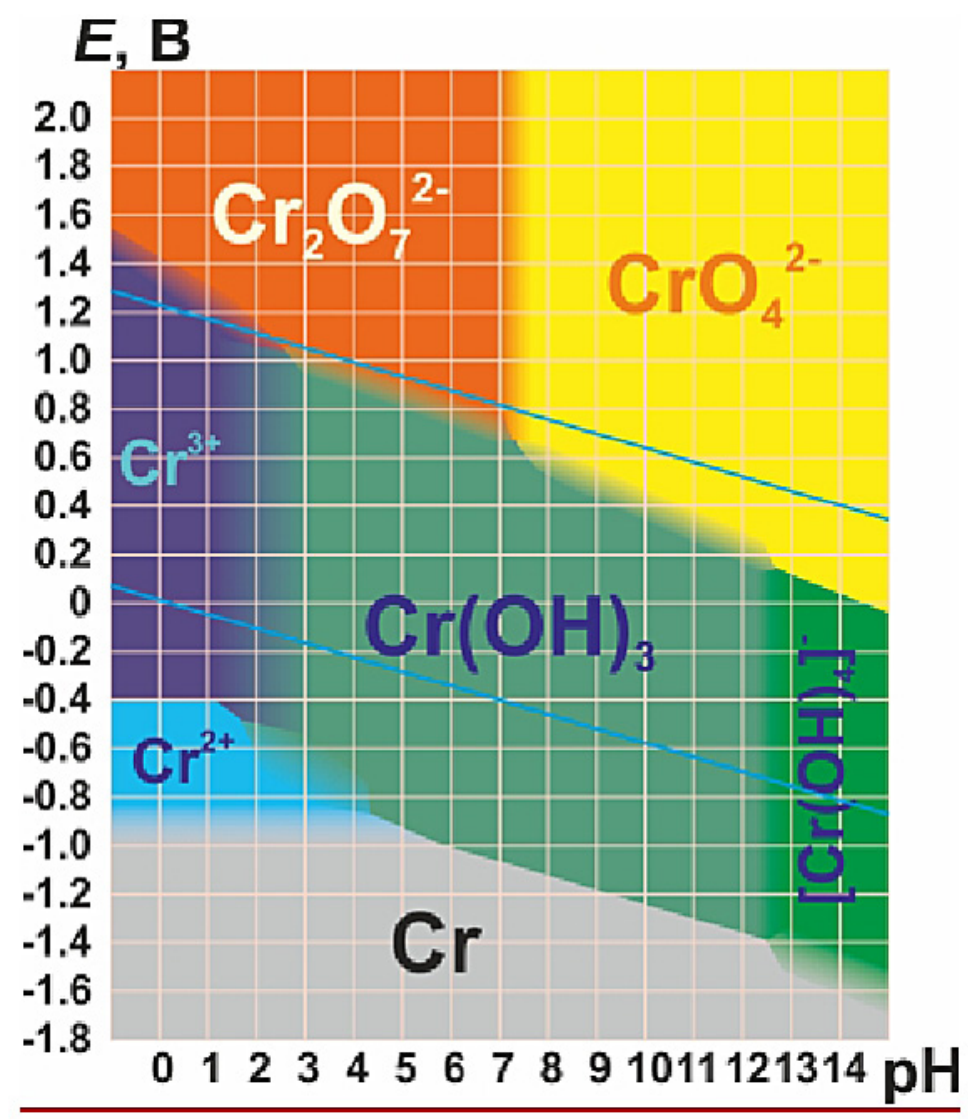

Figure 4. Pourbaix Chromium Diagram [Kotas and Stasicka, 2000] 
Table 6. Physical observation result of Range Finding Test (RFT)

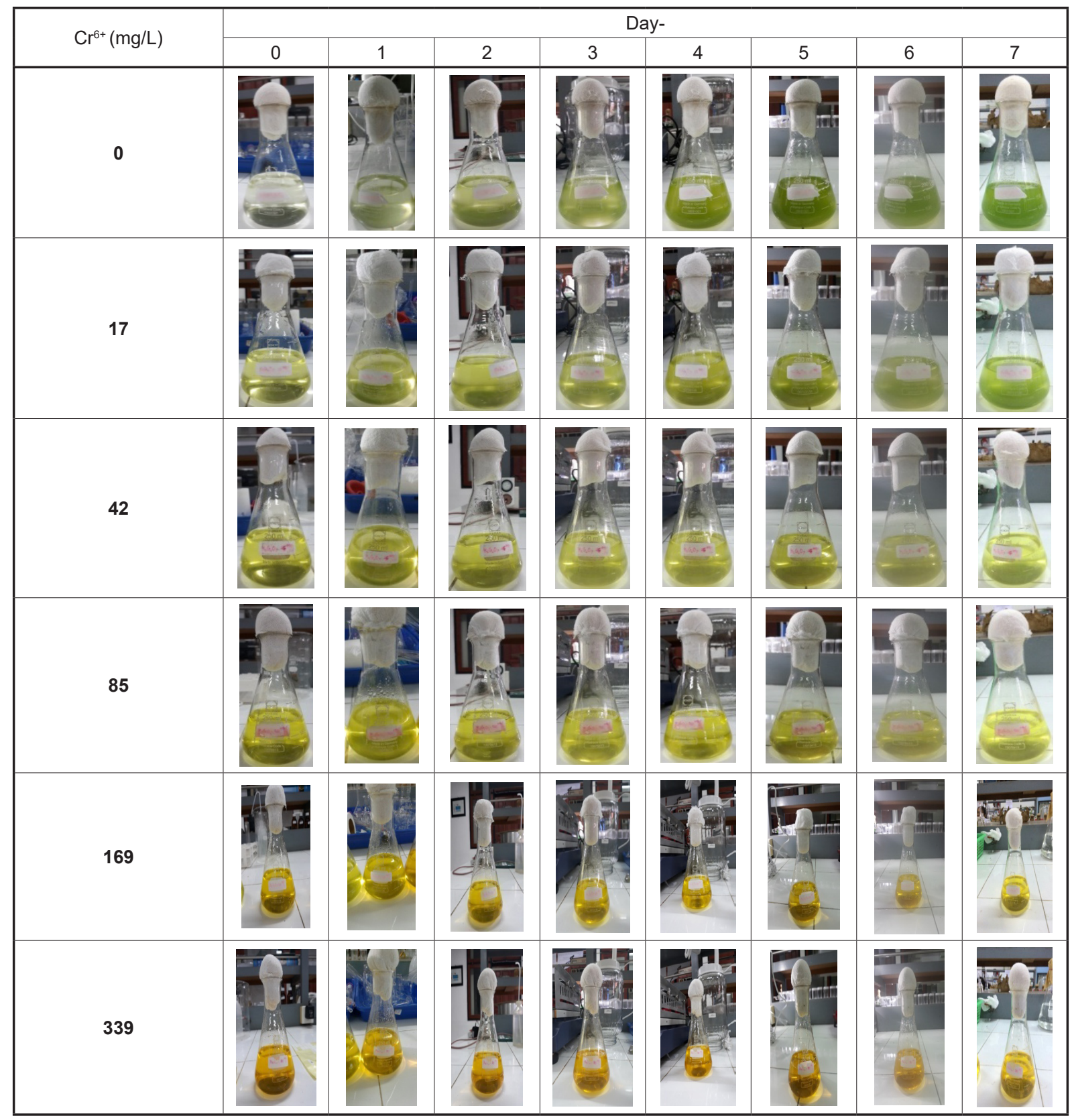

S8 bacteria. This is based on the growth rate and velocity of both microorganisms. This is as bacteria grow faster than microalgae and are still measurable by the end of the test period.

On the other hand, the study by Ali et al. (2015) showed that the addition of Azotobacter to the water environment containing Chlorella vulgaris is known to increase the cell count of Chlorella vulgaris. This is caused by the ability of Azotobacter to produce several phytohormones and vitamins (Fukami, et al., 1997). Azotobacter is a nitrogen fixated bacterium that can fulfill the nitrogen needed for nutrition by Chlorella vulgaris (Ali et al/, 2015).

Table 7. Total chromium concentration determined by AAS method

\begin{tabular}{|c|c|c|c|c|c|c|c|}
\hline \multirow{2}{*}{ Time } & \multicolumn{7}{|c|}{ Consentration of Total Chromium (mg/L) } \\
\cline { 2 - 9 } & Control & K1A & K1B & K2A & K2B & K3A & K3B \\
\hline Initial & 16.72 & 16.70 & 16.69 & 16.68 & 16.65 & 16.71 & 16.73 \\
\hline Effluent & 16.32 & 14.93 & 14.97 & 13.56 & 14.09 & 15.35 & 14.15 \\
\hline
\end{tabular}




\section{CONCLUSION}

The conclusions of this study from the MIC test for the Azotobacter S8 bacteria and the RFT test of the Chlorella vulgaris microalgae show the same result in that both microorganisms are tolerant of chromium up to a concentration of $17 \mathrm{mg} / \mathrm{L}$. The best composition of Azotobacter S8 bacteria and Chlorella vulgaris microalgae in the remediation process is $50 \%$ bacteria and $50 \%$ microalgae with the ratio of inoculum to media being $5: 95 \%$. This can reduce the total concentration of the chromium by $18.68 \%$.

\section{REFERENCES}

1. Abdulla, H.M., Kamal, E.M., Mohamed, A.H., dan El-Bassuony, A.D. (2010). Chromium Removal from Tannery Wastewater Using Chemical and Biological Techniques Aiming Zero Discharge of Pollution. Proceeding of Fifth Scientific Environmental Conference. Zagazig-UNI. 171-183

2. Ali, S.M., Nasr, H.S., Abbas, M.T. (2015). Using Diazotrophic Bacteria for Biomass Production of Microalgae. Egyptian Journal of Environmental Research, 3: 41-52.

3. Anderson, R.A. 2005. Algal Culturing Techniques. China : Elsevier Academic Press, pp. 242-249.

4. APHA, AWWA, WPFC. 2012. Standard Methods for Examination of Water and Wastewater: The 22nd Edition. Washington DC.

5. Benazier, J. Fathima, R. Suganthi, D. Rajvel, M. Padmini Pooja dan B. Mathithumilan. 2010. Bioremediation of Chromium in Tannery Effluent by Microbial Consortia. African Journal of Biotechnology, 9(21): 3140-3143.

6. Brady, D., Letebele, B., Duncan, J.R., Rose, P.D. (1994). Bioaccumulation of metals by Scenedesmus, Selenastrum and Chlorella Algae. Water SA, 20: 213-218.

7. Cervantes, C., Garcia, J.C., Devars, S., Corona, F.G., Tavera, H.L., Guzman, J.C.T., dan Sanchez, R.M. (2001). Interactions of Chromium With Microorganism and Plants. FEMS Microbiology Review, (25): 335-347.

8. Droste, R. 2007. Theory and Practice of Water and Wastewater Treatment.John Wiley andSons. New York. USA.

9. Erni, dan Hindersah, R. (2011). Biosorpsi Kadmium Dan Komposisi Eksopolisakarida Azotobacter Sp Pada Dua Konsentrasi CdCl2. Agrinimal, 1(1): 33-37.

10. Esmaeili, L. 2015. Bioaccumulation and Toxic Effect of Zinc on The Green Alga Chlorella vulgaris.
Thesis Universite Du Quebec A Montreal.

11. Evelyne, R.J., dan Ravisankar, V. (2014). Bioremediation of Chromium Contamination- a Review. International Journal of Research In Earth \& Environmental Sciences, 1(6): 20-26.

12. Farombi, E.O., Adelowo, O.A., danAjimoko, Y.R. 2007. Biomarkers of Oxidative Stress and Heavy Metal Levels as Indicators of Environmental Pollution in African Cat Fish (Clarias gariepinus) from Nigeria Ogun River. International Journal of Environmental Research Public Health, 4(2): 158-5.

13. Fukami, K., Nishijirna, T., dan Ishida, Y. 1997. Stimulative and inhibitory effects of bacteria on the growth of microalgae. Hydrobiologia, 358: 185-191.

14. Glick, B., dan Pasternak. 2001. Molecular Biotechnology. ASM Press. WashingtonDC. USA

15. Haryoto, dan Agustono, W. 2004. Kinetika Bioakumulasi Logam Berat Kadmium oleh Fitoplankton Chlorella sp Lingkungan Perairan Laut. Jurnal Penelitian Sains \&Teknologi, 5(2) : 89-103.

16. Holleman, A.F., Wiberg, E., Wiberg, N. 1985. Chromium. Lehrbuch der Anorganischen Chemie (dalam bahasa German) (edisi ke-91-100). Walter de Gruyter. hlm. 1081-1095. ISBN 3-11-007511-3

17. Hossain, Kamal., Hasan, M., Parvin, M.N., Hasan, M., Islam, S., Haque, A. 2012. Antimicrobial, Cytotoxic and Thrombolitic Activity of Cassia senna Leaves (Family : Fabacee). Journal of Applien Pharmacetical Science, (6): 186-190.

18. Imani, S, Rezael-Zarchi,S., Zand, A.M., Abarg. Hashemi, H.B., Boma, H., Javid, A., dan Abarghouei, H.B. 2011. Hg, Cd and Pb Heavy Metal Bioremidiation by Dunaliella Alga. Journal of MedicinalPlants Research, 5(13) :2775-2780.

19. Imron, M.F dan Purwanti, I.F. 2016. Uji Kemampuan Bakteri Azotobacter S8 dan Azotobacter S8 untuk Menyisihkan Trivalent Chromium $(\mathrm{Cr} 3+)$ pada Limbah Cair. Jurnal Teknik ITS, 5(1).

20. Isnansetyo, A. dan Kurniastuty. 1995. Teknik Kultur Phytopankton dan Zooplankton Pakan Alami 2 untuk Pembenihan Organisme Laut. Yogyakarta: Kanisius.

21. Iyer, A., Mody, K., dan Jha, B. 2005. Biosorption of Heavy Metals by a Marine Bacterium. Pollution Bulletin, 50: 340-343.

22. Kamaludeen, S.P.B., Arunkumar, K.R., Avudainayagam, S., dan Ramasamy, K. 2003. Bioremediation of Chromium Contaminated Environments. Journal of Experimental Biology, 41(9): 972-985.

23. Kaur, H.R. dan Kumar, A. 2014. Bioremediation of Hexavalent Chromium in Wastewater Effluent by Pseudomonas putida (MTCC 102). Journal of Research in Earth \& Environmental Sciences, 1(4): $18-24$.

24. Kawaroe, M., Prartono, T., Sannuddin, A., Sari, D. W., \& Augustine, D. 2010. Mikroalga Potensi dan 
Pemanfaatannya untuk Produksi Bio Bahan Bakar. Bogor: IPB Press.

25. Kotaś, J. dan Stasicka, Z. 2000. Chromium occurrence in the environment and methods of its speciation. Environmental Pollution, 107(3): 263-283.

26. Liang, Z., Liu, Y., Ge, F., Xu Y., Tao, N., Peng, F., dan Wong, M. 2013. Efficiency Assesment and pH Effect in Removing Nitrogen and Phosporus by Algae-Bacteria Combined System of Chlorella vulgaris and Bacillus licheniformis. Journal Chemosphere, (92): 1383-1389.

27. Maligan, J.M., Widayanti, V.T., dan Zubaidah, E. 2015. Identifikasi Senyawa Antimikroba Ekstrak Mikroalga Laut Tetraselmis chuii (Kajian Metode Ekstraksi Maserasi, Jenis Pelarut, dan Waktu Ekstraksi. Jurnal Teknologi Pertanian, 16(3): 195-206.

28. Man K.L., Yusoff, M.I., Uemura, Y., dan Wei, J. 2016. Cultivation of Chlorella vulgaris Using Nutriens Source from Domestic Wastewater for Biodiesel Production: Growth Condition and Kinetic Studies.Renewable Energy, (103): 197-207.

29. Mujtaba, G., \& Lee, K. 2016. Advanced Treatment of Wastewater Using Symbiotic Co-culture of Microalgae and Bacteria. Applied Chemistry for Engineering, 27(1): 1-9.

30. Nacorda, J.O.O., Martinez-Goss, M.R.,dan Torreta, N.K. 2010. Bioremoval and Bioreduction of Chromium (VI)by the Green Microalga, Chlorella vulgarisBeij.,Isolated from Laguna de Bay, Philippines. Phillipine Journal of Science, 139(2): 181-188.

31. Nath, J., dan Ray, L. 2015. Biosorption of Malachite Green from Aqueous Solution by Dry Cells of Bacillus cereus M1 16 (MTCC 5521). Journal of Environmental Chemical Engineering, 3(1): 386-394

32. Nithya, C., Gnanalakshmi, B., dan Pandian, S.K. (2011). Assesment and Characterization of Heavy Metal Resistance in Palk Bay Sediment Bacteria. Marine Environmental Research, 71: 283-294.

33. Oves, M., Khan, M.S., dan Zaidi, A. 2013. Chromium Reducing and Plant Growth Promoting Novel Strain Pseudomonas aeruginosa OSG41 Enhance Chickpea Growth in Chromium Amended Soils. European Journal of Soil Biology, 56(1): 72-83.

34. Pavel, L.V., Diaconu, M., dan Gavrilescu, M.
2012. Studies of Toxicity of Chromium(VI) and Cadmium(II) on Some Microbial Species. International Symponium on Biosorption and Bioremediation. Romania.

35. Purnamawati, F.S., Tri, R.S., dan Munifatul, I. 2015. Potensi Chlorella vulgaris Beijerinck Dalam Remediasi Logam Berat $\mathrm{Pb}$ dan $\mathrm{Cd}$ Skala Laboratorium. Jurnal Bioma, 16(2): 102-113.

36. Rose, P.D., Boshoff, G.A., Van Hille, R.P., Wallace, L.C.M., Dunn, K.M.,dan Duncan, J.R. 1998. An Integrated Algal Sulphate Reducing High Rate Ponding Process for The Treatment of Acid Mine Drainage Wastewaters. Journal Biodegradation, (9): 247-57.

37. Shrivastava, A., Singh, V., Jadon, S., dan Bhadauria, S. 2013. Heavy Metal Tolerance of Three dfifferent Bacteria Isolated from Industrial Effluent. International Journal of Pharmaceutical Research and Bioscience, 2(2): 137-147

38. Silver, S. 1996. Bacterial Resistance to Toxic Metal Ions - A Review. Gene, 179: 9-19.

39. Subashchandrabose, S.R., Ramakrishnan, B., Megharaj, M., Venkateswarlu, K., dan Naidu, R. 2011. Consortia of cyanobacteria/microalgae and bacteria: Biotechnological potential. Journal Biotechnology Advances, 29(6): 896-907.

40. Suminten, N.K., Sudiarta, I.W., dan Simpen, I.N. 2014. Adsorpsi Ion Logam Cr(III) pada Silika Gel dari Abu Sekam Padi Termodifikasi Ligan Difenilkarbazon (Si-DPZon). Jurnal Kimia, 8(2): 231-236.

41. Tam, N.F.Y., Wong, Y.S., dan Simpson, C.G. 1998. Removal of Copper by Free and Immobilized Microalga, Chlorella vulgaris. Journal Wastewater Treatment with Algae, (2): 17-36.

42. Tortora, G.J. 2001. Microbiology an Introduction. 7th ed. World Student Series. SanFrancisco. USA.

43. Triatmojo, A., dan Tangahu, B.V. 2017. Pengaruh Intensitas dan Durasi Paparan Cahaya Light-Emitting Diodes (LEDs) Pada Sistem High Rate Algal Reactor Dalam Pengolahan Limbah Cair Laundry. Tugas Akhir Jurusan Teknik Lingkungan ITS.

44. USEPA. 2010. IRIS, Toxicological Review of Hexavalent Chromium 2010. External Review Draft). U.S.Environmental Protection Agency, Washington, DC EPA/635/R- 10/004A, 2010. 